\title{
Study on the Effect of Design Coefficients on Load-bearing Capacity of Circular RCFT Columns
}

\author{
Wei Hua ${ }^{1, a}$, Duan Zhen-zhong ${ }^{2, b}$, Li Peng-peng ${ }^{3, ~ c}$, Wang Hai-jun ${ }^{1, d}$ \\ ${ }^{1}$ College of Architectural Engineering, Shenyang University of Technology, Shenyang, Liaoning, \\ 110870, China \\ ${ }^{2}$ Henan province Huixian City Construction Bureau, Huixian, Henan, 453600, China \\ ${ }^{3}$ Dalian Lushunkou District Personnel workstations, Dalian, Liaoning, 116041, China \\ aweiflower1973@yahoo.com.cn, bduan20061124@163.com, 'Ipp_419@163.com, \\ ${ }^{\mathrm{d}}$ corresponding author: wang_navy@hotmail.com
}

Keywords: concrete strength, diameter-thickness ratio, steel bar, RCFT column, yield strength

\begin{abstract}
Based on the Japan recommendations, the formula of yield strength for RCFT (reinforced concrete filled steel tube) columns was proposed, the effect of experimental coefficient such as concrete strength, diameter-thickness ratio of steel tube, number of steel bars on yield strength of RCFT was analyzed, and strength evaluation formula for RCFT column is tested by experimental results. As a result, the proposed evaluation formula can evaluate yield strength of RCFT column properly.
\end{abstract}

\section{Introduction}

Concrete-filled steel tube is a new structure. It is based on the spiral structure of reinforced concrete and steel pipe structure. In recent years, concrete-filled steel tubular structure was used in high-level and large-scale construction at home and abroad, because of the advantages in its structural performance and its construction techniques. It has become an important form in civil engineering. With increasingly theoretical study of CFT (concrete filled steel tube) structure, there is more and more projects used concrete-filled steel tubular structure [1]-[4].

Based on the recommendations, the formula of yield strength for RCFT (reinforced concrete filled steel tube) was proposed, the effect of experimental coefficient such as concrete strength, diameter-thickness ratio of steel tube, number of reinforcing bars on yield strength of RCFT was analyzed, and strength evaluation formula for RCFT column is tested by experimental results. As a result, the proposed evaluation formula can evaluate yield strength of RCFT column properly.

\section{Outline of Compression Test and Proposal of Compressive Strength Evaluation Formula for RCFT Column}

Outline of Column Test Specimen. The section size and details of test specimens are presented in Fig.1, respectively. According to filling situation, there are five types of test specimens: high-strength CFT, low-strength CFT, RCFT with thin cover, RCFT with thick cover, and RCFT with double reinforcements. The thickness of steel pipe is $3.2 \mathrm{~mm}, 4.5 \mathrm{~mm}$, and $6.0 \mathrm{~mm}$. A total of 15 test specimens are made. The size of specimens is $150 \mathrm{~mm}$ in the diameter, $300 \mathrm{~mm}$ in height. The compressive strength of concrete at an age of 28 days was $19.2 \mathrm{~N} / \mathrm{mm} 2,50.0 \mathrm{~N} / \mathrm{mm} 2$, respectively. CFT columns are filled with low strength concrete and high strength concrete, and RCFT columns are only filled with low-strength concrete. Steel tubes are made of SS400, and reinforcing bars are made of SR295.

Test Set-up and Measurements. Based on the recommendations [5], compressive yield strength evaluation equation for CFT column is:

$$
N_{u}=\left(\beta-\frac{(D-2 t)}{2(D-t)} k \cdot \alpha\right) A_{s} \sigma_{s y}+\gamma_{c u} \cdot A_{c} \sigma_{c B} .
$$


In this study, CFT was reinforced with steel bars, so Eq. 1 can be expressed as:

$$
N_{u}=\left(\beta-\frac{(D-2 t)}{2(D-t)} k \cdot \alpha\right) A_{s} \sigma_{s y}+A_{c} \sigma_{c B}+\sum A_{s r} \sigma_{s r y} \text {. }
$$

in which $L$ is length of steel tube, $t$ is thickness of steel tube and $D$ is diameter of steel tube, $A s, A c$, $A s r$ is cross section area of steel tube, concrete, and reinforcing bars, $\sigma_{s y}, \sigma_{s r y}$ is yield strength of steel tube and reinforcing bar, respectively, $\sigma_{c B}$ is compressive strength of concrete, $\gamma_{c u}$ is reduction factor of concrete under the confinement pressure $\sigma_{r}$. According to the recommendations, here it is $1 . \alpha, \beta$ is coefficient reflected variation of yield strength of steel tube in circumferential and axial direction, and here, $\alpha=-0.19, \beta=0.89 . k$ is a coefficient by the Richart experiment which carried out the triaxial compression test of the concrete by the lateral static water pressure, and it is about 3-4. It is referred to 4.1 in RDC.

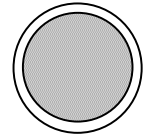

High-strength CFT

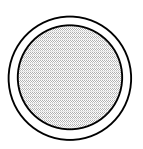

Low-strength CFT

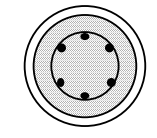

RCFT with thin cover

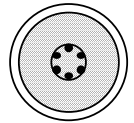

RCFT with thick cover

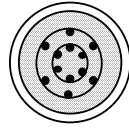

RCFT with

double reinforcements
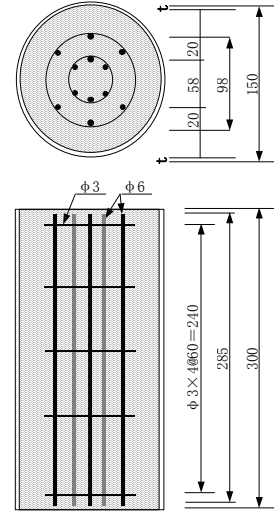

Test specimen (unit:mm)

Fig. 1 Shape and size of the column specimen's cross-section

Comparison between Calculated Value and Experimental Value. Yield strength by experimental data, by formula (1) and by the proposal formula (2) are shown in Table 1. Experimental value of axial compression yield strength was obtained from load-strain curves of CFT and RCFT columns' surface. As the yield point is not so clear, the load when the strain is $0.2 \%$ is taken as the yield strength. From Table 1, it is shown that the difference between calculated value and by experimental value is about $10 \%$. Therefore, formula (2) can be used to evaluate the axial compression yield strength.

The Effect of Test Coefficients on Axial Compression Yield Bearing Capacity of RCFT Columns. The difference between calculated value by the proposal formula (2) and experimental value is within $10 \%$. Therefore, formula (2) can be used to analyze the effect of design parameters on axial yield bearing capacity of RCFT columns. The diameter of steel tube used in the course of analysis is $100-1000 \mathrm{~mm}$, the thickness of steel tube is $1-50 \mathrm{~mm}$, reinforcing bars' numbers is $0-20$, the yield strength of steel tube is $300-500 \mathrm{~N} / \mathrm{mm}^{2}$, and the axial compressive strength of concrete is $10-70$ $\mathrm{N} / \mathrm{mm}^{2}$.

The relationship of axial compression yield load and reinforcing bars' numbers (the diameterthickness ratio of steel tube is 10, 30, 50, and 150) are shown in Fig. 2. In Fig. 2, the yield strength of steel tube is $360 \mathrm{~N} / \mathrm{mm}^{2}$; the axial compressive strength of concrete is $20 \mathrm{~N} / \mathrm{mm}^{2}$. The relationship of axial compression yield load and yield strength of steel tube is shown in Fig. 3. In Fig. 3, reinforcing bars' number is 6 ; the axial compressive strength of concrete is $20 \mathrm{~N} / \mathrm{mm}^{2}$. The relationship of axial compression yield load and concrete axial compression strength are shown in Fig. 4. In Fig. 4, reinforcing bars' number is 6 ; the yield strength of steel tube is $360 \mathrm{~N} / \mathrm{mm}^{2}$. The relationship of axial compression yield load and diameter of steel tube are shown in Fig. 5.

In Fig. 5, reinforcing bars' number is 6; the yield strength of steel tube is $360 \mathrm{~N} / \mathrm{mm}^{2}$; the axial compressive strength of concrete is $20 \mathrm{~N} / \mathrm{mm}^{2}$. From Fig. 2, it can be understood that reinforcing bars' number has inconspicuous effect on the axial compression yield bearing capacity of RCFT columns, even if the thickness of steel tube is changed, the effect is still very small. From Fig. 3 and Fig. 4, it can be seen that the slope of the straight line changes with the variation of diameter-thickness 
ratio. When the diameter-thickness ratio is small, the yield strength of steel tube has a greater effect on axial compression yield bearing capacity of RCFT columns; when the diameter-thickness ratio is great, the axial compression strength of concrete has a greater effect on it. It can be seen from Fig. 5 that In the case of same diameter-thickness ratio and materials' characteristics, it is obvious that the greater area of cross-section of the column can sharply improve the axial compression yield bearing capacity. Compression test specimens used to verify proposal formula have small cross-section and diameter-thickness ratio $(25<D / t<47)$, so yield strength of steel tube has great effect on experimental result. While in the case of RCFT column is used for large-scale buildings, or reinforced concrete filled in hollow steel tube column is used as reinforcing measurement after the earthquake, the area of column's cross-section is larger, so the axial compression strength of concrete has greater effect on its axial compression yield load.
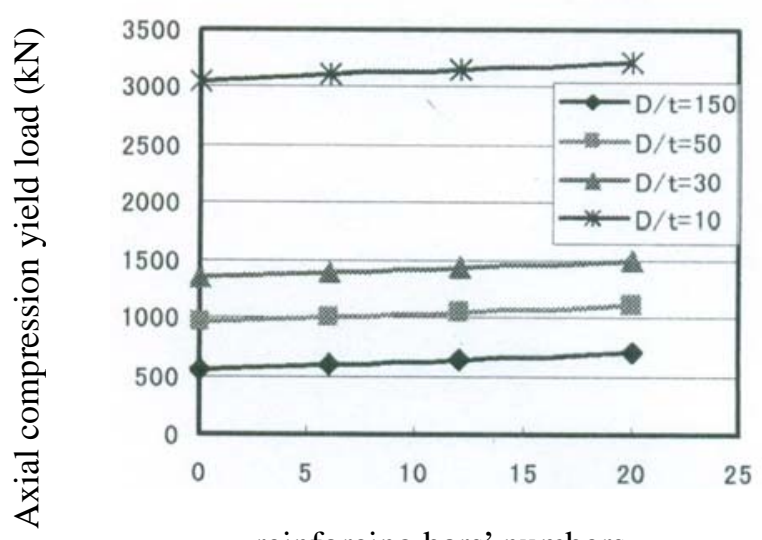

reinforcing bars' numbers

Fig. 2 The relationship of axial compression yield load and reinforcing bars’ numbers

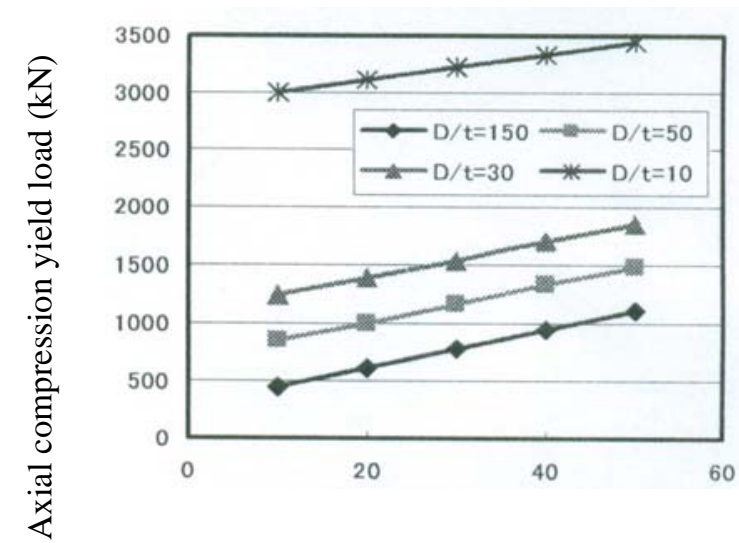

Concrete axial compression strength $\sigma_{\text {св }}\left(\mathrm{N} / \mathrm{mm}^{2}\right)$

Fig. 4 The relationship of axial compression yield load and concrete axial compression strength

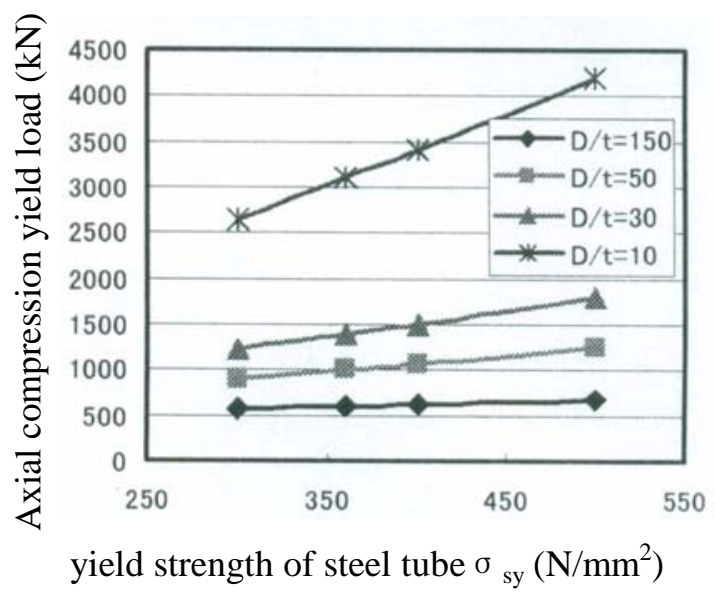

Fig. 3 The relationship of axial compression yield load and yield strength of steel tube

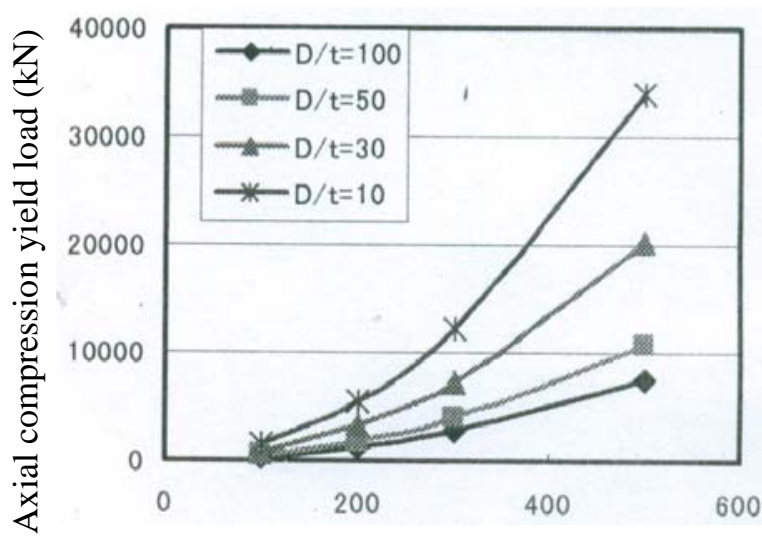

Diameter of steel tube (mm)

Fig. 5 The relationship of axial compression yield load and diameter of steel tube Table 1 Comparison between calculated value and experimental value of axial compression yield strength

\begin{tabular}{|c|c|c|c|c|}
\hline $\begin{array}{c}\text { Types of } \\
\text { specimens }\end{array}$ & $\begin{array}{c}\text { Thickness of } \\
\text { steel tube } \\
(\mathrm{mm})\end{array}$ & $\begin{array}{c}\text { Experimental } \\
\text { value } \\
(\mathrm{kN})\end{array}$ & $\begin{array}{c}\text { Calculated } \\
\text { value } \\
(\mathrm{kN})\end{array}$ & $\begin{array}{c}\text { Difference of } \\
\text { calculated value and } \\
\text { experimental value } \\
(\%)\end{array}$ \\
\hline \multirow{2}{*}{$\begin{array}{c}\text { Low strength } \\
\text { CFT }\end{array}$} & 3.2 & 931.29 & 871.80 & -6.4 \\
\cline { 2 - 5 } & 4.5 & 1176.92 & 1071.50 & -9.0 \\
\hline \multirow{2}{*}{$\begin{array}{c}\text { High strength } \\
\text { CFT }\end{array}$} & 6.0 & 1180.45 & 1264.42 & 7.1 \\
\cline { 2 - 5 } & 3.2 & 1431.39 & 1370.63 & -4.2 \\
\hline RCFT with & 6.5 & 1823.69 & 1552.42 & -14.9 \\
\hline
\end{tabular}




\begin{tabular}{|c|c|c|c|c|}
\hline \multirow{2}{*}{ thin cover } & 4.5 & 1191.06 & 1118.29 & -6.1 \\
\cline { 2 - 5 } & 6.0 & 1201.66 & 1311.21 & 9.1 \\
\hline \multirow{2}{*}{$\begin{array}{c}\text { RCFT with } \\
\text { thick cover }\end{array}$} & 3.2 & 980.77 & 918.59 & -6.3 \\
\cline { 2 - 5 } & 4.5 & 1183.99 & 1118.29 & -5.5 \\
\hline \multirow{2}{*}{$\begin{array}{c}\text { RCFT with } \\
\text { double } \\
\text { reinforcements }\end{array}$} & 6.0 & 1201.66 & 1311.21 & 9.1 \\
\cline { 2 - 5 } & 3.2 & 994.90 & 965.38 & -3.0 \\
\cline { 2 - 5 } & 4.5 & 1238.77 & 1165.08 & -5.9 \\
\hline
\end{tabular}

\section{Conclusions}

1) When the diameter-thickness ratio is small, the yield strength of steel tube has a greater effect on axial compression yield bearing capacity of RCFT columns; when the diameter-thickness ratio is great, the axial compression strength of concrete has a greater effect on it.

2) In the case of same diameter-thickness ratio and materials' characteristics, it is obvious that the greater area of cross-section of the column can sharply improve the axial compression yield bearing capacity.

3) Reinforcing bars' number has inconspicuous effect on the axial compression yield bearing capacity of RCFT columns. But according to test results, it can largely improve deformation performance of RCFT columns after steel tubes yield by inserting steel bars in filled concrete. So RCFT columns have better seismic performance and restorability after earthquake.

\section{Acknowledgement}

The work reported in this paper was supported by “Liaoning BaiQianWan Talents Program” Fund (2010921077), Liaoning Provincial Educational Department Fund (L2010412), Liaoning Provincial Educational Department Fund (L2010411), Shenyang Science and Technology Plan Fund (F10-205-1-08). The supports are gratefully acknowledged.

\section{References}

[1] Chen H. T., Zhong S. T., Zhang S. M., Three Dimensional Stress-Strain Relations of Concrete in Concrete-filled Steel Tubes, Journal of Harbin University of C. E \&Architecture, Vol. 6 (2005), p. 12-16.

[2] Lu M. Q., Yang Q. S., Nonlinear Finite Element Analysis on Mechanical Behavior of Concrete Filled Rectangular Steel Tubular Column, Journal of Shenyang University of Technology, Vol. 34 (2012), p. 224-230.

[3] Gan C. SH., The Elastic-plastic Constitution Equation and Ultimate Capacity to Steel Tube Filled Concrete, Journal of Chang-Sha Communications University, Vol. 3 (2002), p. 68-74.

[4] Pei W. J., Zhao J. H. et al. Analysis of Section Types of Concrete Filled Steel Tube and Its Load Capacity, Journal of Architecture and Civil Engineering, Vol. 23 (2006), p. 49-53.

[5] AIJ, Recommendations for the Design and Fabrication of Tubular Truss Structures in Steel, Architectural Institute of Japan, (2002). 